\title{
Endoscopic diagnosis and treatment of biliary obstruction due to acute cholangitis and acute pancreatitis secondary to Fasciola bepatica infection
}

\author{
Kemal Dolay, M.D., ${ }^{1}$ Mustafa Hasbahçeci, M.D., ${ }^{2}$ Engin Hatipoğlu, M.D., ${ }^{3}$ \\ Fatma Ümit Malya, M.D., ${ }^{1}$ Adem Akçakaya, M.D. ${ }^{1}$ \\ ${ }^{1}$ Department of General Surgery, Bezmialem Vakif University Faculty of Medicine, Istanbul-Turkey \\ 2Department of General Surgery, Medical Park Fatih Hospital, İstanbul-Turkey \\ ${ }^{3}$ Department of General Surgery, İstanbul University Cerrahpaşa Faculty of Medicine, İstanbul-Turkey
}

\begin{abstract}
In the differential diagnosis of biliary obstruction with unknown etiology, biliary fascioliasis should be considered in endemic and nonendemic regions. After diagnostic evaluation, endoscopic retrograde cholangiopancreatography (ERCP) was performed for etiological evaluation and/or treatment of biliary obstruction in five patients with a mean age of 55.8 years. Endoscopic sphincterotomy and cholangiogram revealed linear filling defects in the biliary system. Fasciola hepatica parasites were extracted using balloon and basket catheters in two and three patients, respectively. No morbidity or mortality was observed. F. hepatica infection should be considered as a differential diagnosis of biliary obstruction with unknown etiology in endemic and non-endemic regions. ERCP can be the standard diagnostic and/or therapeutic procedure in cases of biliary obstruction due to fascioliasis. Due to slippery and gel-like characteristics of the parasite, use of a basket catheter in semi-opened position may be required in case of unsuccessful extraction using a balloon catheter.
\end{abstract}

Keywords: Biliary tract; endoscopic retrograde cholangiopancreatography; Fasciola hepatica.

\section{INTRODUCTION}

Fasciola hepatica is a well-known helminth parasite, which has important economic and public health consequences, especially in subtropical regions and temperate climates. ${ }^{[1]}$ In the hepatic phase, young flukes first migrate to the liver parenchyma. After 6-7 weeks, they enter into the bile ducts of definitive hosts and become sexually mature. In the biliary phase, adult flukes can remain asymptomatic for many years. Besides the fact that biliary complications are more common in tropical countries, biliary fascioliasis causing biliary obstruction, cholangitis, or pancreatitis should be considered as a differential diagnosis of biliary obstruction with unknown etiology in endemic regions. ${ }^{[2-4]}$ For such cases, endoscopic retrograde cholangiopancreatography $(E R C P)$ can be the standard diagnostic and/or therapeutic procedure in which the leaf-like nematode is detected and extracted from the biliary system. ${ }^{[2]}$

For the parasites located in the main bile ducts and presenting as complicated biliary obstruction, certain maneuvers and instruments can be used, including balloon catheters, biopsy forceps, and snare or basket catheters. ${ }^{[5]}$ However, due to the slippery, gel-like structure of Fasciola, extraction using balloon catheter cannot be successful in all the cases; in such cases, it may be logical to use a basket catheter in a semiopened position for extraction.

We aimed to present the technical details of biliary fascioliasis diagnosed during ERCP performed for the etiological eval-

Cite this article as: Dolay K, Hasbahçeci M, Hatipoğlu E, Malya FÜ, Akçakaya A. Endoscopic diagnosis and treatment of biliary obstruction due to acute cholangitis and acute pancreatitis secondary to Fasciola hepatica infection. Ulus Travma Acil Cerrahi Derg 2018;24:71-3

Address for correspondence: Kemal Dolay, M.D.

Bezmialem Vakıf Üniv. Tıp Fakültesi Hastanesi, Genel Cerrahi Anabilim Dalı, Vatan Caddesi, Fatih, İstanbul, Turkey.

Tel: +90 212 - 4531700 E-mail: dolayk@yahoo.com

Ulus Travma Acil Cerrahi Derg 2018;24(I):7I-73 DOI: 10.5505/tjtes.20I7.89490 Submitted: 24.01.2017 Accepted: 13.09.20I7

Copyright 2018 Turkish Association of Trauma and Emergency Surgery 
uation and/or endoscopic treatment of biliary obstruction in five patients.

\section{CASE SERIES}

\section{Patients}

There were five patients who were diagnosed with biliary fascioliasis during ERCP which was performed for biliary obstruction due to a presumptive diagnosis of acute cholangitis $(n=3)$ and acute pancreatitis $(n=2)$ between January 2000 and January 2016. The mean age of the patients was 55.8 (range, 34-60) years, with a female to male ratio of $4: 1$. There was no history of travelling to high-endemic regions for fascioliasis in these patients. Institutional review board approval was obtained. The study was performed according to the Declaration of Helsinki. Informed consent was not obtained from patients due to the retrospective design of this case series.

As an initial step, all patients underwent hepatobiliary ultrasound; three patients then underwent magnetic resonance cholangiopancreatography. Laboratory and ultrasonographic findings indicated obstructive jaundice probably caused due to choledocholithiasis in two patients, and magnetic resonance imaging indicated filling defects in the biliary system in the remaining three patients; therefore, all the patients underwent ERCP (Fig. I).

\section{Technique}

Standard sphincterotome and/or precut sphincterotomy with a needle knife papillotome were performed to cannulate the naive papilla after achieving an en face position. Cholangiogram revealed linear filling defects in the distal common bile duct and main hepatic duct in three and two patients, respectively. After sufficient endoscopic sphincterotomy, balloon catheter was used to extract the live parasites in two patients (Fig. 2). However, basket catheter in a semi-opened position was necessitated in three patients due to the slippery and gel-like structure of the parasite (Fig. 3a, 3b). There were one and two live F. hepatica parasites (Fig. 4) in three

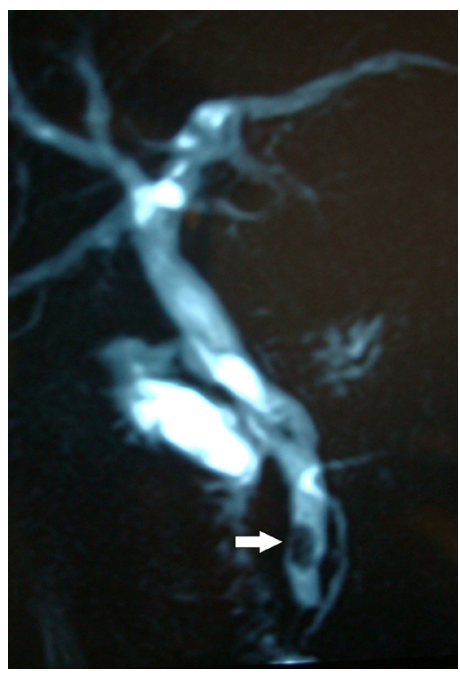

Figure 1. Magnetic resonance cholangiopancreatography of a patient showing a hypointense filling defect (white arrow) at the distal common bile duct which mimics a gallstone.

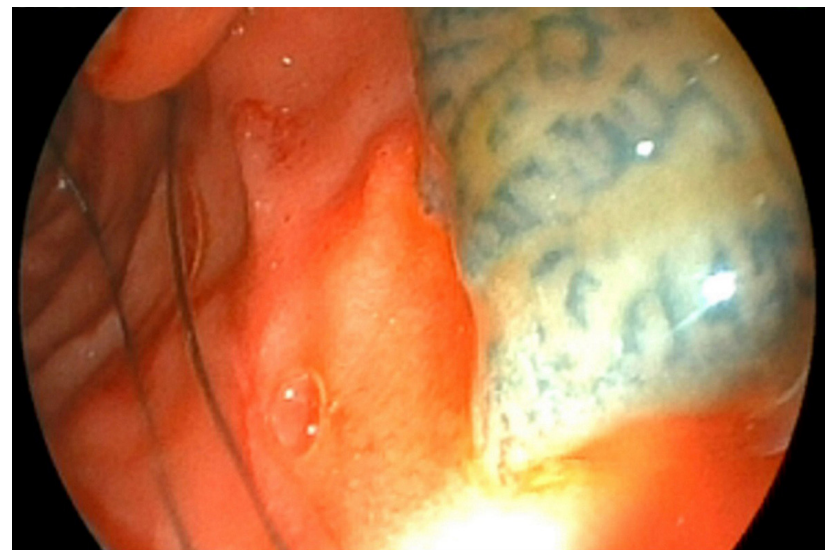

Figure 2. Endoscopic view of Fasciola hepatica.
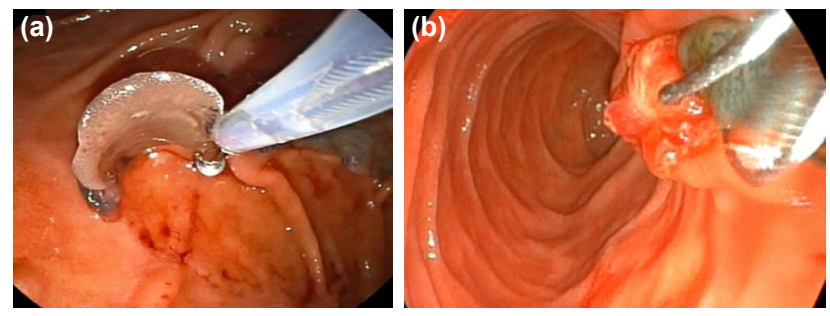

Figure 3. (a) Use of a basket catheter in semi-opened position. (b) Endoscopic extraction of Fasciola hepatica using a basket catheter.

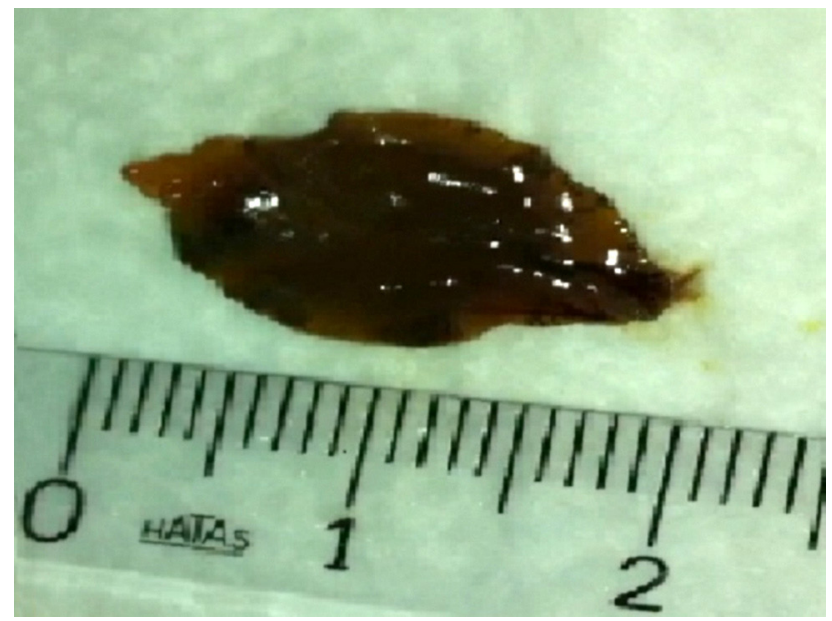

Figure 4. Live Fasciola hepatica parasite in vitro.

and one patients, respectively. In one patient, the extracted parasite was thought to be dead due to the absence of any movement. No morbidity or mortality was observed. After the procedure, a single dose of triclabendazole $(10 \mathrm{mg} / \mathrm{kg}$; Egaten 250; Novartis, Switzerland) was prescribed to all the patients. After the intervention, clinical findings were completely resolved and biochemical abnormalities normalized within an average of ten days.

\section{DISCUSSION}

In non-endemic areas for F. hepatica, the underlying pathologies for patients with obstructive jaundice usually include choledocholithiasis or biliary malignancy. ${ }^{[2,6]}$ However, biliary 
obstruction caused by $F$. hepatica may also lead to the misdiagnosis of cholangiocarcinoma or choledocholithiasis. Furthermore, in endemic countries for F. hepatica, an accurate diagnosis in the presence of obstructive jaundice cannot be reached using conventional imaging techniques because these parasites rarely cause biliary obstruction..$^{[5]}$ Because of the technical limitations, images obtained using conventional imaging techniques are of lesser significance than those obtained using ERCP. The detection of filling defects in the biliary system has been the first radiological finding without a specified pathology. Even at the beginning of biliary evaluation during ERCP, it has been reported that the first impression is bile duct stones or sludge. ${ }^{[6]}$ Therefore, such parasites should be considered while evaluating patients with obstructive jaundice, particularly in endemic areas of the world.

For all the patients included in this case series, hepatobiliary ultrasound was performed as an initial step. Although magnetic resonance cholangiopancreatography following ultrasound was planned at the secondary level, ERCP was directly performed following ultrasound in two patients due to the presence of laboratory findings that suggested biliary obstruction associated with acute cholangitis and ultrasonographic findings that suggested choledocholithiasis. Therefore, ERCP was used for both diagnostic and therapeutic purposes for treating mechanical biliary obstruction in two patients. Additionally, ERCP can be regarded as the gold standard for diagnostic and therapeutic purposes in such patients when the diagnosis is confirmed.

For the endoscopic treatment of biliary fascioliasis, endoscopic sphincterotomy is the first step for the extraction of the parasite. Extraction of the parasite is mostly achieved using a balloon catheter. ${ }^{[2,5,7,8]}$ However, the slippery and gel-like structure of the parasite may cause difficulty in extracting the parasites via a balloon catheter, as observed in two of our cases. For such patients, a basket catheter in a semi-opened position can be used for the extraction of the parasites. ${ }^{[6,9]}$

In conclusion, biliary fascioliasis may have variable clinical presentations, and ERCP plays a crucial role both in diagnosis and treatment. Additionally, a semi-opened basket catheter may increase the success of extraction of live Fasciola parasites from the bile duct.

\section{Conflict of interest: None declared.}

\section{REFERENCES}

1. Moazeni M, Ahmadi A. Controversial aspects of the life cycle of Fasciola hepatica. Exp Parasitol 2016;169:81-9. [CrossRef]

2. Ha JS, Choi HJ, Moon JH, Lee YN, Tae JW, Choi MH, et al. Endoscopic Extraction of Biliary Fascioliasis Diagnosed Using Intraductal Ultrasonography in a Patient with Acute Cholangitis. Clin Endosc 2015;48:579-82. [CrossRef]

3. Haseeb AN, El-Shazly AM, Arafa MA, Morsy AT. Clinical, laboratory and ultrasonography features of proven human fascioliasis. J Egypt Soc Parasitol 2003;33:397-412.

4. Hawramy TA, Saeed KA, Qaradaghy SH, Karboli TA, Nore BF, Bayati NH. Sporadic incidence of Fascioliasis detected during hepatobiliary procedures: a study of 18 patients from Sulaimaniyah governorate. BMC Res Notes 2012;5:691. [CrossRef]

5. Ezzat RF, Karboli TA, Kasnazani KA, Hamawandi AM. Endoscopic management of biliary fascioliasis: a case report. J Med Case Rep 2010;4:83. [CrossRef]

6. Niknam R, Kazemi MH, Mahmoudi L Pharm D. Three Living Fasciola Hepatica in the Biliary Tract of a Woman. Iran J Med Sci 2015;40:465-8.

7. Bektaş M, Dökmeci A, Cinar K, Halici I, Oztas E, Karayalcin S, et al. Endoscopic management of biliary parasitic diseases. Dig Dis Sci 2010;55:1472-8. [CrossRef]

8. Boşnak VK, Karaoğlan İ, Sahin HH, Namiduru M, Pehlivan M, Okan V, et al. Evaluation of patients diagnosed with fascioliasis: A six-year experience at a university hospital in Turkey.J Infect Dev Ctries 2016;10:389-94.

9. Wang M, Pleskow DK. Fasciola hepatica. Endoscopy 2013;45 Suppl 2 UCTN:E207-8.

\title{
OLGU SERISİ - ÖZET
}

\section{Fasciola hepatica'ya ikincil akut kolanjit ve akut pankreatitin yol açtığı biliyer obstrüksiyonun endoskopik tanı ve tedavisi}

\author{
Dr. Kemal Dolay, ${ }^{1}$ Dr. Mustafa Hasbahçeci, ${ }^{2}$ Dr. Engin Hatipoğlu, ${ }^{3}$ Dr. Fatma Ümit Malya, ${ }^{1}$ Dr. Adem Akçakaya \\ 'Bezmialem Vakıf Üniversitesi Tıp Fakültesi, Genel Cerrahi Anabilim Dalı, İstanbul \\ ${ }^{2}$ Medical Park Fatih Hastanesi, Genel Cerrahi Kliniği, İstanbul \\ ${ }^{3}$ Istanbul Üniversitesi Cerrahpaşa Tıp Fakültesi, Genel Cerrahi Anabilim Dalı, İstanbul
}

Biliyer Fasciola hepatica enfestasyonu, endemik ve non-endemik bölgelerde etiyolojisi bilinmeyen biliyer tıkanıklığın ayıııc tanısında olası bir sebep olarak düşünülmelidir. Tanısal değerlendirme sonrası safra yollarında obstrüksiyon saptanan ortalama yaşları 55.8 yıl olan beş hastaya etiyolojik değerlendirme ve/veya endoskopik tedavi için endoskopik retrograd kolanjiyopankreatografi uygulandı. Endoskopik sfinkterotomi ve kolanjiyogram, biliyer sistemde safra dolum defektlerini gösterdi. Balon ve sepet kateteri kullanılarak sırasıyla iki ve üç hastada Fasciola hepatica parazitleri çıkartıldı. Morbidite veya mortalite görülmedi. Fiziksel ve laboratuvar bulgular 10 gün içinde kademeli azalarak normalleşti. Fasciola hepatica, endemik ve nonendemik bölgelerde etiyolojisi bilinmeyen safra yolu tıkanıklığı ayırıcı tanııında öncelikle düşünülmelidir. Fasciola hepatica'ya bağlı safra yolu tıkanıklı̆̆ı olgularında endoskopik retrograd kolanjiyopankreatografi standart tanı ve/veya tedavi yöntemidir. Parazitin kaygan ve jel benzeri yapısından dolayı, balon kateterin yetersiz kaldığı durumlarda, yarı-açık pozisyonda sepet kateterin kullanılması gerekebilir.

Anahtar sözcükler: Biliyer sistem; endoskopik retrograd kolanjiyopankreatografi; Fasciola hepatica.

Ulus Travma Acil Cerrahi Derg 2018;24(I):71-73 doi: 10.5505/tjtes.2017.89490 